Original Article

\title{
Shading minimizes the effects of water deficit in Campomanesia Xanthocarpa (Mart.) 0 . Berg seedlings
}

\author{
Sombreamento minimiza o efeito do déficit hídrico em mudas de Campomanesia \\ xanthocarpa (Mart.) O. Berg
}

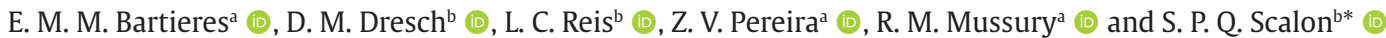 \\ aUniversidade Federal da Grande Dourados - UFGD, Faculdade de Ciências Biológicas e Ambientais, Dourados, MS, Brasil \\ bUniversidade Federal da Grande Dourados, Faculdade de Ciências Agrárias, Dourados, MS, Brasil
}

\begin{abstract}
The objective of this study was to evaluate the activity of antioxidant enzymes, the functioning of the photosystem II and quality of $C$. xanthocarpa seedlings cultivated under intermittent water deficit and shading levels and the influence of shading on recovery potential after suspension of the stress conditions. The seedlings were subjected to three levels of shading $(0,30$, and $70 \%)$, six periods of evaluation (start: 0 days; $1^{\text {st }}$ and $2^{\text {nd }}$ photosynthesis zero: $1^{\text {st }}$ and $2^{\text {nd }} \mathrm{P} 0 ; 1^{\text {st }}$ and $2^{\text {nd }}$ recovery: $1^{\text {stand }} 2^{\text {nd }} \mathrm{REC}$; and END), and two forms of irrigation (control: periodically irrigated to maintain $70 \%$ substrate water retention capacity, and intermittent irrigation: suspension of irrigation). The plants subjected to intermittent irrigation conditions at $0 \%$ shading showed a reduction in water potential $(\Psi \mathrm{w})$ and potential quantum efficiency of photosystem II (Fv/Fm) and maximum efficiency of the photochemical process (Fv/F0) and an increase in basal quantum production of the non-photochemical processes (F0/Fm). Superoxide dismutase (SOD) activity was higher in the leaves than in the roots. The C. xanthocarpa is a species sensitive to water deficit but presents strategies to adapt to an environment under temporary water restriction, which are more temporary are most efficient under shading. The seedlings with water deficit at all levels of shading exhibited higher protective antioxidant activity and lower quality at $0 \%$ shading. The shading minimizes prevents permanent damage to the photosystem II and after the re-irrigation, the evaluated characteristics showed recovery with respect to the control group, except POD and SOD activities in the leaves.
\end{abstract}

Keywords: enzyme, chlorophyll $a$ fluorescence, photochemistry, abiotic stress.

\begin{abstract}
Resumo
O objetivo deste estudo foi avaliar a atividade de enzimas antioxidantes, o funcionamento do fotossistema II e a qualidade de mudas de $C$. xanthocarpa cultivadas sob déficit hídrico intermitente e níveis de sombreamento e a influência do sombreamento sobre o potencial de recuperação após suspensão das condições de estresse. As mudas foram submetidas a três níveis de sombreamento (0, 30 e 70\%), seis períodos de avaliação (início: 0 dias; $1^{\underline{a}}$ e $2^{\underline{a}}$ fotossíntese zero: $1^{\underline{a}}$ e $2^{\underline{a}} \mathrm{PO} ; 1^{\underline{a}}$ e $2^{\underline{a}}$ recuperação: $1^{\underline{a}}$ e $2^{\mathrm{a}} \mathrm{REC}$; e final), e duas formas de irrigação (controle: periodicamente irrigado para manter $70 \%$ da capacidade de retenção de água do substrato, e irrigação intermitente: suspensão da irrigação). As plantas submetidas às condições de irrigação intermitente a $0 \%$ de sombreamento apresentaram redução do potencial hídrico ( $\Psi$ w) e eficiência quântica potencial do fotossistema II (Fv/Fm) e máxima eficiência do processo fotoquímico (Fv/F0) e aumento da produção quantica basal dos processos não fotoquímicos (F0/Fm). A atividade da superóxido dismutase (SOD) foi maior nas folhas do que nas raízes. C. xanthocarpa é uma espécie sensível ao déficit hídrico, mas apresenta estratégias para se adaptar a um ambiente com restrição hídrica temporária, sendo mais eficientes sob sombreamento. As mudas com déficit hídrico em todos os níveis de sombreamento exibiram maior atividade antioxidante protetora e menor qualidade no sombreamento $0 \% .0$ sombreamento minimiza danos permanentes ao fotossistema II e após a re-irrigação, as características avaliadas apresentaram recuperação em relação ao grupo controle, exceto atividades de POD e SOD nas folhas.
\end{abstract}

Palavras-chave: enzima, fluorescencia da clorofila $a$, fotoquímica, estresse abiótico.

\section{Introduction}

Previous studies have shown that climate change is responsible for irregular patterns of precipitation and temperature, resulting in different types of stress that alter the metabolism and development of plants. According to the review by Rodrigues et al. (2015), this is a topic that has aroused the interest of researchers since the last decade,

*e-mail: silvanascalon@ufgd.edu.br

Received: October 19, 2020 - Accepted: January 5, 2021 
highlighting the importance of considering its consequences on the distribution or mortality of tree species. The effects of stress reflect on seedling quality, growth, and adaptation mechanisms. Thus, it is important to study the behaviour of plants exposed to environmental stresses because some of these plants are not adapted to areas with little soil water availability or variations in luminosity (Reis et al., 2016; Chirino et al., 2017), which makes them vulnerable.

Water deficit due to alterations in luminosity may impair the development of plants, and photosystem II is affected by intense radiation, making it necessary to alter the photosynthetic apparatus and dissipate the excess energy absorbed; this also alters the fluorescence parameters of chlorophyll a (Franco et al., 2005; Costa et al., 2015). Moreover; excess light usually increases the ambient temperature and vapour pressure deficit, intensifying the effects of the water deficit and closure of the stomata and resulting in the lower uptake of $\mathrm{CO}_{2}$ and, consequently, lower photosynthetic rate (Favaretto et al., 2011).

The stress generated by adverse environmental factors stimulates the antioxidant metabolism, which plays an important role in ameliorating the damage caused by drought, extreme temperatures, pollutants, ultraviolet radiation, and high/low light levels. Resende et al. (2019) highlighted that little information on the biochemical responses of plants to water stress addresses endangered species, most of which refer to species of economic interest. Thus, to better use available water resources and optimize seedling production for recomposition projects, it is necessary to evaluate the efficiency of the photosynthetic apparatus and antioxidant activity of the seedlings.

Campomanesia xanthocarpa (Mart.) O. Berg (Myrtaceae), a fruit tree species found in the Brazilian Atlantic Forest and Cerrado Biomes (Teleginski et al., 2018; CNCFlora, 2012). The leaf, fruit, bark, wood, and stem all have considerable potential for commercial and medicinal exploitation, being used to treat various diseases, such as reducing blood cholesterol levels in hypercholesterolemia (Klafke et al., 2010). Little information is available on water and light requirements of C. xanthocarpa seedlings, given that such information might assist horticulturists or farmers in their cultivation practices, minimizing seedlings mortality rates and, consequently, production costs, as well as favour management practice and success in recuperation projects of degraded areas. C. xanthocarpa although sensitive to water deficit, exhibits a potential for recovery of photosynthesis and growth characteristics with the resumption of irrigation when cultivated under 30 and $70 \%$ shading (Bartieres et al., 2020). These authors observed in their review that this species is classified as late secondary requiring shaded sites.

To understand the physiological and adaptive responses of C. xanthocarpa to the water deficit associated with different luminosities, we tested the hypothesis that shading minimizes the effects of water deficit, activating antioxidant metabolism, and reducing damage to the photosystem II, which enable adjustments to the stressful conditions and resumption of metabolism photochemical and growth. The objective of this study was to evaluate the activity of antioxidant enzymes, the functioning of the photosystem II and quality of C.xanthocarpa seedlings cultivated under intermittent water deficit and different light availability and the influence of shading on recovery potential after suspension of the stress conditions.

\section{Material and Methods}

\subsection{Study area and vegetable material}

The present study was performed in the nursery of the Faculty of Agrarian Sciences at the Federal University of Grande Dourados (UFGD), municipality of Dourados, State Mato Grosso do Sul, Brazil.

Campomanesia xanthocarpa seedlings (height, $15 \mathrm{~cm}$ ) were cultivated in pots with a capacity of $8 \mathrm{~kg}$ containing Dystroferric Red Latosol with clay and sand texture (1:1 v:v).

The experiment was carried out in a place covered with either no plastic shading or plastic with a black nylon screen known as Sombrite ${ }^{\circledR}$ to simulate shading of $30 \%$ and $70 \%$. At each shade level, the seedlings were divided into two blocks, the first one with continuous irrigation and the second with intermittent irrigation, with a total of 48 seedlings per shade level.

\subsection{Treatments}

The experiment was carried out at three levels of shading $(0,30$, and $70 \%)$. During the experiment, the control plants (continuous irrigation $[\mathrm{CI}]$ ) were periodically irrigated to maintain $70 \%$ substrate water retention capacity. For the plants under treatment characterized by stress (intermittent irrigation [II]), irrigation was suspended until the photosynthetic rate was close to zero, when the seedlings again received water daily. The substrate water retention capacity was maintained at $70 \%$, until the photosynthetic rate was at least $80 \%$ of the control value at the same level of shading (for exemple: IC and II $0 \%$ shading; IC and II 30\% shading, and IC and II 70\% shading) and it was called the first recovery. A second cycle of irrigation suspension was performed, and the seedlings were evaluated up to 45 days after the second recovery.

The evaluations were performed at the beginning of the experimental period (Start: 0 days) and the others when verified in any of the treatments, a condition of photosynthesis close to zero ( $1^{\text {st }}$ and $2^{\text {nd }}$ Photosynthesis zero - P0: 13 and 44 days after irrigation suspension) and zero photosynthesis recovery in at least one of the treatments ( $1^{\text {st }}$ and $2^{\text {nd }}$ Recovery: 25 and 52 days after reirrigation) and the last evaluation was characterized as the END (106 days after the start of the experiment).

Because the natural environmental conditions resulted in different light availability and variations in temperature and relative humidity of the air, only the shading of the seedling cultivation environments was controlled, and the temperatures and relative humidity oscillated according to the climatic conditions in the experimental period, which externally ranged from 25 to $35{ }^{\circ} \mathrm{C}$ and 85 to $90 \% \mathrm{RH}$.

\subsection{Evaluations}

\subsubsection{Leaf water potential}

The leaf water potential ( $\Psi \mathrm{w})$ of four seedlings was obtained from the second pair of fully expanded leaves from the apex to the base, between 10:00 and 11:00 am using a Scholander-type pressure chamber (Portable Plant Water Status Console - Model 3115), immediately after leaf collection. 


\subsubsection{Chlorophyll index and chlorophyll a fluorescence analysis}

The chlorophyll index was determined using a chlorophyll meter (SPAD 502; Minolta). The initial fluorescence (F0), maximum efficiency of the photochemical process in photosystem II (Fv/F0), potential quantum efficiency of photosystem II (Fv/Fm), and basal quantum production of non-photochemical processes of photosystem II (F0/Fm) were obtained from the data on the fluorescence of chlorophyll $a$ measured using a model OS-30p portable fluorometer (Opti-Sciences Chlorophyll Fluorometer). All evaluations were performed using four seedlings per treatment in the morning, between 8:00 am and 11:00 am, on fully expanded and previously marked leaves. The leaves were subjected to a period of 30 minutes of adaptation to the dark using adapter clips to allow all the reaction centers in this leaf region to reach the open condition, that is, complete oxidation of the photosynthetic electron transport system.

\subsubsection{Antioxidant enzyme activity}

Superoxide dismutase (SOD; EC 1.15.1.1) and peroxidase (POD; EC 1.11.1.7) activities in leaves and roots were measured according to the methodology adapted from Broetto (2014).

\subsubsection{Dickson quality index}

Seedling quality was assessed by Dickson quality index (DQI), which was calculated using the following equation: DQI = TDM/[(H/SD)+(SDM/RDM)] (Dickson et al., 1960), where TDM = total dry mass $(\mathrm{g}), \mathrm{H}=$ height $(\mathrm{cm})$, and $\mathrm{SD}=$ stem base diameter $(\mathrm{mm}), \mathrm{SDM}=$ shoot dry mass $(\mathrm{g})$, $\mathrm{RDM}=$ root dry mass $(\mathrm{g})$.

\subsection{Experimental design and statistical analysis}

The experiment was carried out using a completely randomized design $(3 \times 2 \times 6$; three levels of shading $\times$ two irrigation conditions $\times$ six evaluation periods) with four repetitions using two seedlings.
The statistical analysis system SISVAR 5.3 (Ferreira, 2010) was used to analyse the results. The data were submitted to analysis of variance, and significant effects of the means for shading were compared with the Tukey test. The experimental periods were evaluated using the Scott Knott test and irrigation conditions with the Bonferroni $t$-test, all at $5 \%$ probability.

\section{Results}

\subsection{Water potential ( $\Psi w)$}

The leaf water potential ( $\Psi w)$ was lower in the intermittent irrigation treatments than in the continuous irrigation treatments and lower in the seedlings cultivated at $0 \%$ shading. The lowest $\Psi \mathrm{w}$ was observed in the $2^{\text {nd }} \mathrm{P} 0$ and did not recover after re-irrigation. Shading was observed to maintain the $\Psi \mathrm{w}$ of seedlings higher when the irrigation was intermittent (Figure 1a and 1b).

\subsection{Chlorophyll a fluorescence}

With respect to fluorescence characteristics, an increase in the initial fluorescence (F0) in the $1^{\text {st }} \mathrm{P0}$ ) was observed, but it was more expressive in the $2^{\text {nd }} \mathrm{P} 0$ in the seedlings that received $0 \%$ shading under intermittent irrigation conditions (Figure 2a). These results suggest that seedlings under water deficit were stressed when compared with the control seedlings.

The potential quantum efficiency of photosystem II (Fv/Fm) was lower (0.67 electron quantum $\left.{ }^{-1}\right)$ in plants under $0 \%$ shading and intermittent irrigation (Figure $2 \mathrm{~b}$ ). Similarly, the maximum efficiency of the photochemical process in photosystem II (Fv/F0) of plants under $30 \%$ and $70 \%$ shading was higher, especially in the $2^{\text {nd }} \mathrm{P} 0$, with the highest values found in plants under continuous irrigation (Figure 3a, 3b and 3c). The basal quantum production of the non-photochemical processes of photosystem II (F0/Fm) was higher $(0.39)$ at the $2^{\text {nd }} \mathrm{PO}$ for plants grown at $0 \%$ shading, and the lowest values were generally observed under 30 and $70 \%$ shading conditions; the values recovered at the end of the evaluations (Figure $3 c$ ).

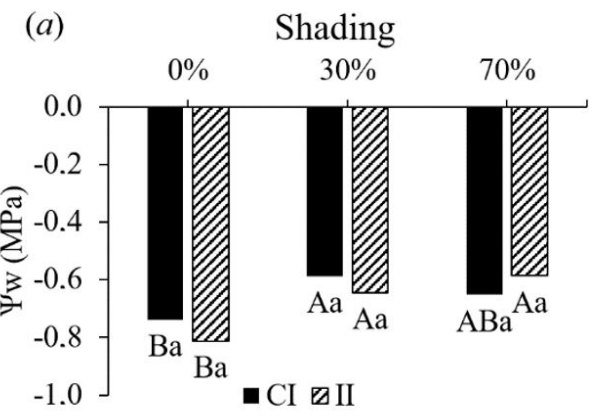

(b)

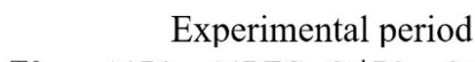
T0 $\quad 1^{\text {st }} \mathrm{P} 0 \quad 1^{\text {st }} \mathrm{REC} \quad 2^{\text {nd }} \mathrm{P} 0 \quad 2^{\text {nd }} \mathrm{REC} \quad \mathrm{END}$

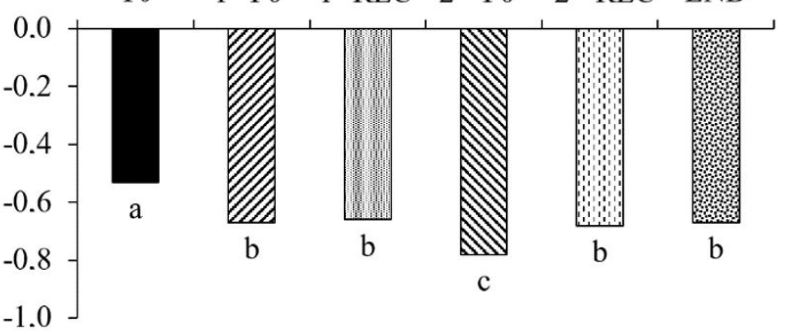

Figure 1. Water potential ( $\Psi \mathrm{w})$ of Campomanesia xanthocarpa seedlings as a function of continuous irrigation (CI) and intermittent (II) conditions, shading (0, 30, and 70\%) (a) and experimental period (Start: T0, $1^{\text {st }}$ and $2^{\text {nd }}$ Photosynthesis Zero: P0, $1^{\text {st }}$ and $2^{\text {nd }}$ Recovery: REC and END); (b). Uppercase letters compare the same irrigation condition in different shading. Lowercase letters compare the same shading in different irrigation conditions and shading (Figure 1a). 


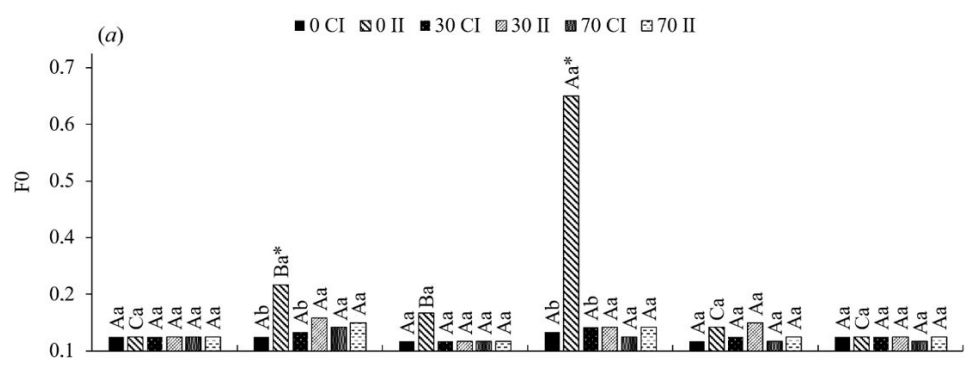

(b)

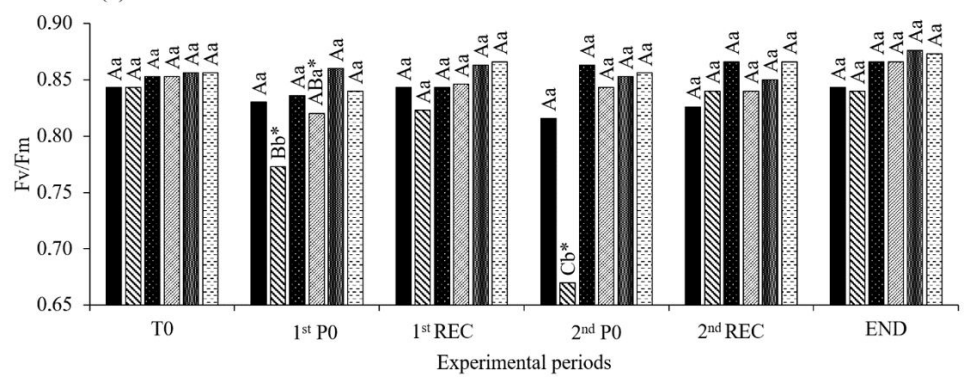

Figure 2. Initial fluorescence - F0 (a) and the potential quantum efficiency of photosystem II - Fv/Fm (b) of Campomanesia xanthocarpa seedlings as a function of continuous irrigation (CI) and intermittent (II) conditions, shading $(0,30$, and $70 \%$ ) and experimental period (Start: T0, $1^{\text {st }}$ and $2^{\text {nd }}$ Photosynthesis Zero: P0, $1^{\text {st }}$ and $2^{\text {nd }}$ Recovery: REC and END). Uppercase letters compare the same shading and irrigation conditions in different experimental periods. Lowercase letters compare the same irrigation condition and period in different shading. The asterisk compares irrigation conditions in the same shading and period. The means of shading were compared by the Tukey test, the experimental periods by the Scott Knott test, and the irrigation conditions by the Bonferroni T test. In all cases, 5\% probability was used.
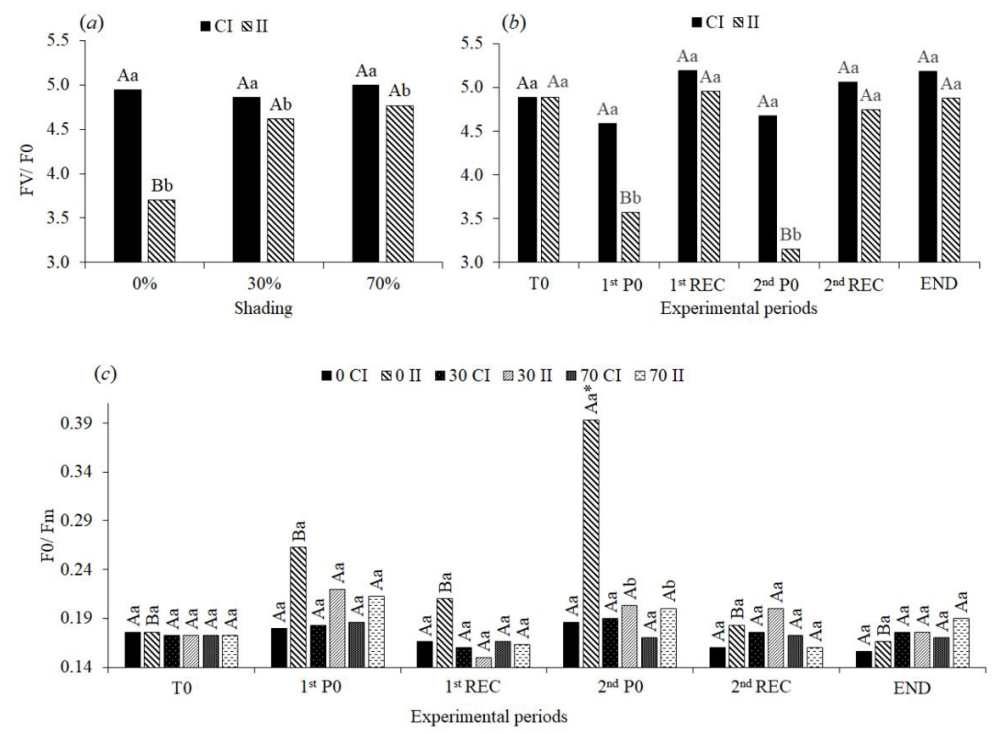

Figure 3. Maximum efficiency of the photochemical process in photosystem II - Fv/F0 (a, b) and basal quantum production of the non-photochemical processes of photosystem - F0/Fm (c) of Campomanesia xanthocarpa seedlings as a function of continuous irrigation (CI) and intermittent (II) conditions, shading $(0,30$, and $70 \%)$ and experimental period (Start - T0, $1^{\text {st }}$ and $2^{\text {nd }}$ Photosynthesis Zero - PO, $1^{\text {st }}$ and $2^{\text {nd }}$ Recovery - REC and END). Uppercase letters compare the same irrigation condition in different shading (a) and different experimental periods (b). Lowercase letters compare different irrigation conditions in the same shading (a) and different experimental periods (b). Uppercase letters compare the same shading and irrigation conditions in different experimental periods. Lowercase letters compare the same irrigation condition and period in different shading. The asterisk compares irrigation conditions in the same shading and period (c). The means of shading were compared by the Tukey test, the experimental periods by the Scott Knott test, and the irrigation conditions by the Bonferroni T test. In all cases, $5 \%$ probability was used. 


\subsection{Quality of seedlings and chlorophyll index}

Plants under $0 \%$ shading and intermittent irrigation presented a lower DQI whereas the other treatments did not show any variations (Figure $4 \mathrm{a}$ and $4 \mathrm{~b}$ ).

The highest chlorophyll index values were observed in the $2^{\text {nd }}$ REC and at the end of the evaluations, and water restriction did not significantly change this characteristic, which remained stable until the $2^{\text {nd }}$ REC (Figure $4 \mathrm{c}$ ).

\subsection{Antioxidant activity}

A higher POD activity was found in the leaves than in the roots (Figure 5b and 5c), mainly in plants under $0 \%$ shading and intermittent irrigation. At the end of the experimental period, regardless of shading, plants that underwent the water deficit did not present peroxidase values close to the control values in the leaves, suggesting no recovery in this organ (Figure 5a).

Similar to POD activity, SOD activity in the leaves (Figure 6a) and roots (Figure 6b-d) was higher in the plants grown under $0 \%$ shading and intermittent irrigation. The highest values were observed in the $2^{\text {nd }} \mathrm{P} 0$ for leaves, and they did not vary between the periods in the case of the roots. Regardless of shading, SOD activity did not recover and remained higher in the leaves.

\section{Discussion}

Campomanesia xanthocarpa plants under water deficit conditions showed a reduction in water potential $(\Psi \mathrm{W})$ in the leaves in the $2^{\text {nd }} \mathrm{P} 0$, with mean values of
$-0.78 \mathrm{MPa}(\Psi \mathrm{w})$, a value lower than that observed in the control plants $(-0.53 \mathrm{MPa})$. The highest potentials were observed in the recovery stage of the stressed plants, indicating that the water deficit did not cause irreversible damage to the water absorption capacity of the roots and water transport to the aerial part. This reduction affected the physiological and metabolic processes of the plant, impacting photosynthesis and photochemistry, similar to that reported in the literature (Franco et al., 2005).

However, shading allowed a smaller loss of water by the substrate, reflected by the stomata opening for a longer period, and favoured greater assimilation of $\mathrm{CO}_{2}$ (data not shown) similar to that observed by Bartieres et al. (2020) for the same species and cultivation condition. Water potential of the leaves determines water fluxes in the soil-plant-atmosphere system and influences cell growth, photosynthesis, and productivity (Taiz et al., 2017).

In periods of lower water availability, in general, the initial fluorescence (F0) and the basal quantum production of non-photochemical processes in photosystem II (F0/ Fm) showed an increase and the photochemical process in photosystem II (Fv/F0) showed maximum efficiency. This behavior of the characteristics of the chlorophyll $a$ fluorescence may be related to the reduction of the chlorophyll content in the leaves in the same period, and we believe that a smaller amount of energy was absorbed by the antenna complex, that is, it was not transmitted, leading to greater changes in photosynthetic capacity due to stress caused by water deficiency.

This result emphasizes the reduction of the functionality of the photosynthetic apparatus because of the damage to

(a)

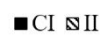

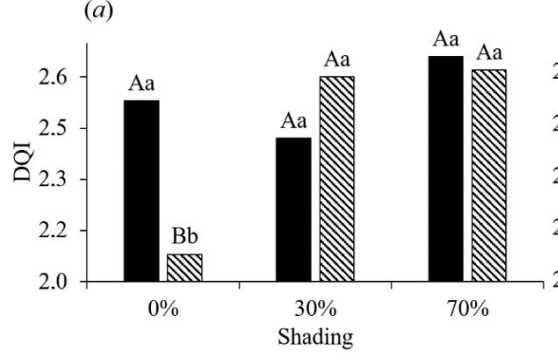

(b)

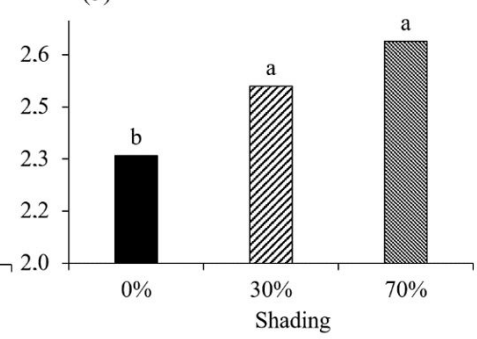

(c)

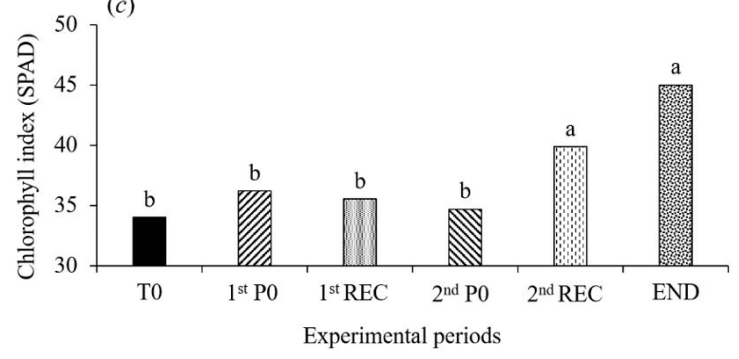

Figure 4. Dickson quality index (DQI) (a, b) and chlorophyll index (c) of Campomanesia xanthocarpa seedlings as a function of continuous irrigation (CI) and intermittent (II) conditions, shading (0, 30, and 70\%) and experimental period (Start: T0, $1^{\text {st }}$ and $2^{\text {nd }}$ Photosynthesis Zero: P0, $1^{\text {st }}$ and $2^{\text {nd }}$ Recovery: REC and END). Uppercase letters compare the same irrigation condition in different shading. Lowercase letters compare different irrigation conditions in the same shading (a). The means of shading were compared with the Tukey test; experimental periods, Scott Knott test; and irrigation conditions, Bonferroni $t$-test. In all cases, 5\% probability was used. 


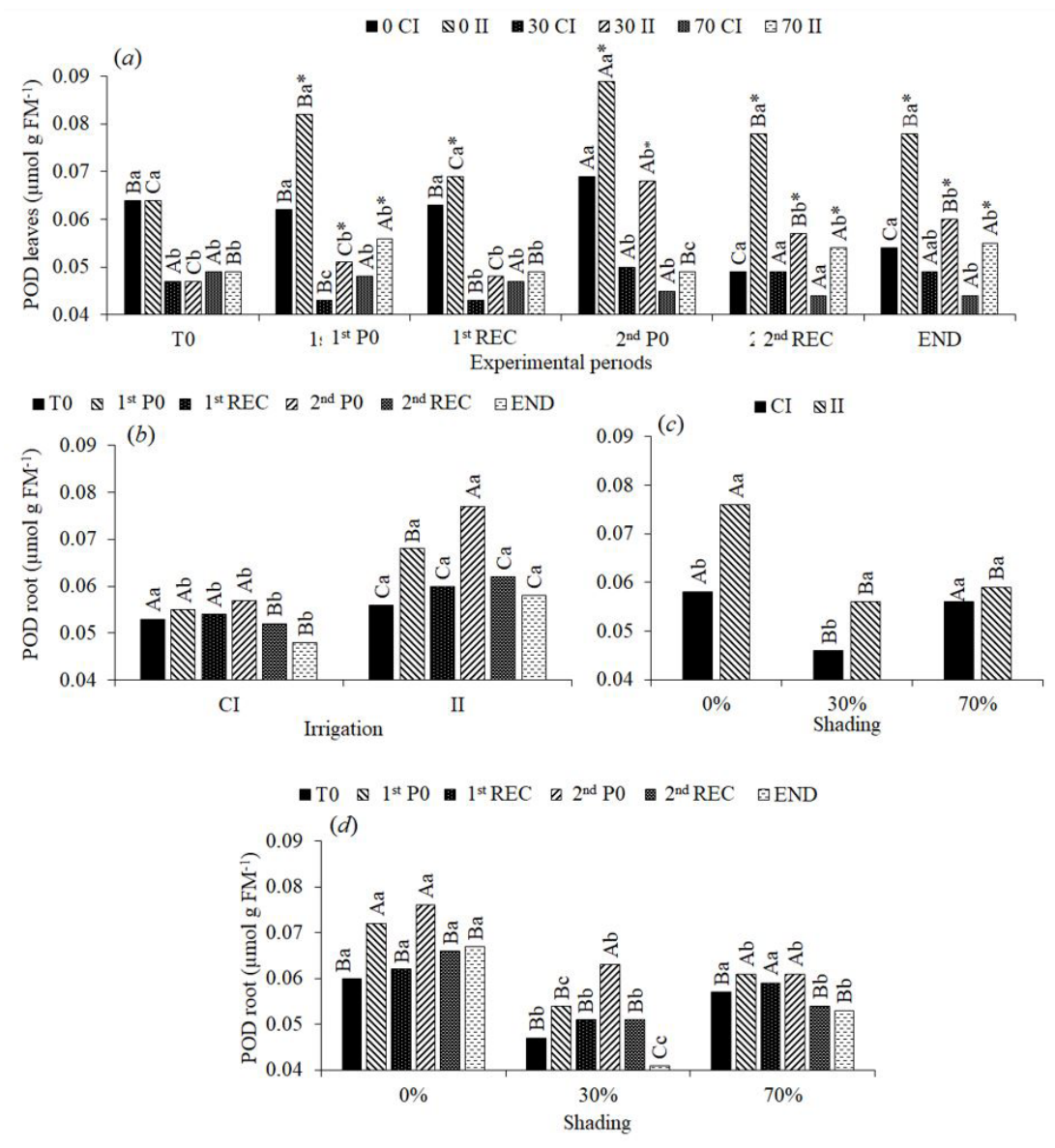

Figure 5. Peroxidase activity (POD) in leaves (a) and roots (b, c, d) of Campomanesia xanthocarpa seedlings as a function of shading $(0,30$ and $70 \%)$, continuous irrigation $(\mathrm{CI})$ and intermittent (II) conditions, and experimental period (Start - T0, $1^{\text {st }}$ and $2^{\text {nd }}$ Photosynthesis Zero - P0, $1^{\text {st }}$ and $2^{\text {nd }}$ Recovery - REC and END). Uppercase letters compare the same shading and irrigation conditions in different experimental periods. Lowercase letters compare the same irrigation condition and period in different shading. The asterisk compares irrigation conditions in the same shading and period (a). Upper case letters compare the same irrigation condition in different shading and the same shading in the different period (d). Lowercase letters compare different irrigation conditions in the different periods (b) and same shading (c) and same period in the different shading (d). The means of shading were compared by the Tukey test, the experimental periods by the Scott Knott test, and the irrigation conditions by the Bonferroni $\mathrm{T}$ test. In all cases, $5 \%$ probability was used.

the reaction centre of photosystem II or reduction in the transfer capacity of the excitation energy from the antenna to the reaction centre (Maxwell and Johnson, 2000; Baker, 2008). Thus, we observed that chlorophyll a fluorescence characteristics were detected in periods when the plants were stressed, and this is reliable for evaluating plants of other species (Maxwell and Johnson, 2000; Rohácek, 2002; Baker and Rosenqvist, 2004; Bento et al., 2016).

The reduction in $\mathrm{Fv} / \mathrm{Fm}$ and $\mathrm{Fv} / \mathrm{FO}$ accompanied by an increase in $\mathrm{FO}$ and $\mathrm{F} 0 / \mathrm{Fm}$, mainly in the $2^{\text {nd }} \mathrm{P0}$ and under $0 \%$ shading, reflect the stress of the seedlings. The values considered for the potential quantum efficiency of photosystem II $(\mathrm{Fv} / \mathrm{Fm})$ of several plant species vary between 0.75 and 0.85 (Maxwell and Johnson, 2000; Baker and Rosenqvist, 2004). A lower variation, as observed in C. xanthocarpa (0.68), has been related to physiological mechanisms and plant growth site (Li et al., 2004).
The results suggest the occurrence of photo-inhibitory damage to the reaction centres of photosystem II, causing a reduction in photosynthesis in this period of stress. A similar reduction in $\mathrm{Fv} / \mathrm{Fm}$ was observed by Bento et al. (2016) for the same species under water deficit; a significant decline in the photosynthetic rate was also found, which might be related to the reduction in electron transfer.

Reductions in $\mathrm{Fv} / \mathrm{FO}$ in the $0 \%$ shading and $1^{\text {st }}$ and $2^{\text {nd }}$ P0 were also observed. In this study, the values of this characteristic in the seedlings were very low, since these values are considered adequate for maintaining the functionality of the reaction centers of photosystem II when they are between 4 and 6 (Rohácek, 2002). However, the seedlings recovered their ideal values at the $2^{\text {nd }} \operatorname{Rec}$ and at the end of the experiment.

The mean reference values for basal quantum production by the non-photochemical processes of photosystem II $(\mathrm{FO} / \mathrm{Fm})$ are between 0.14 and 0.20 , and an increase in 


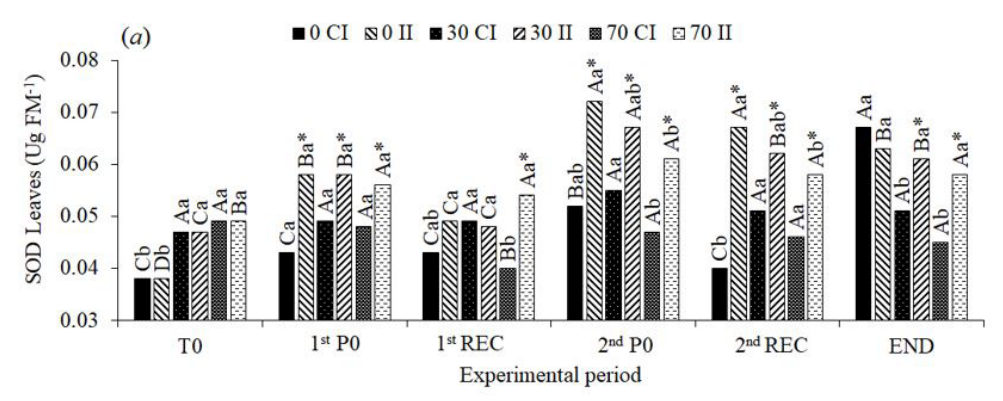

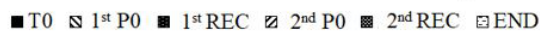

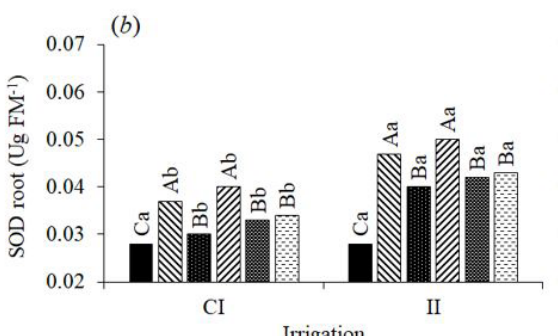

(c)

- CI \& II

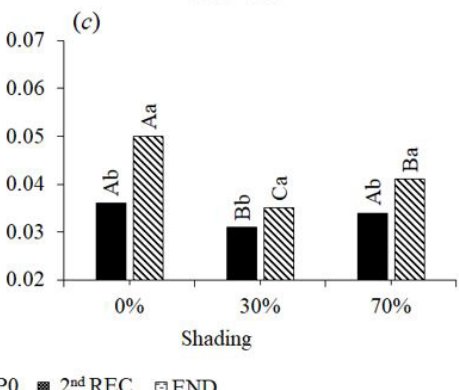

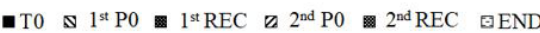

(d)

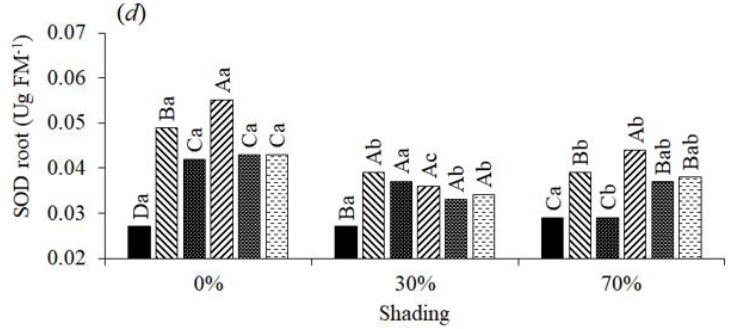

Figure 6. Superoxide dismutase (SOD) activity in leaves (a) and o roots (b, c, d) of Campomanesia xanthocarpa seedlings as a function of shading $(0,30$ and $70 \%)$, continuous irrigation $(\mathrm{CI})$ and intermittent (II) conditions, and experimental period (start - T0, $1^{\text {st }}$ and $2^{\text {nd }}$ photosynthesis zero $-\mathrm{PO}, 1^{\text {st }}$ and $2^{\text {nd }}$ Recovery - REC and END). Uppercase letters compare the same shading and irrigation conditions in different experimental periods. Lowercase letters compare the same irrigation condition and period in different shading. The asterisk compares irrigation conditions in the same shading and period (a). Uppercase letters compare the same condition shading in the different period (d). Lowercase letters compare different irrigation conditions in the different periods (b) and same shading (c) and same period in the different shading (d). The means of shading were compared by the Tukey test, the experimental periods by the Scott Knott test, and the irrigation conditions by the Bonferroni $\mathrm{T}$ test. In all cases, $5 \%$ probability was used.

this value is considered an indication of stress (Rohácek, 2002). For C. xanthocarpa seedlings, we verified an increase in this production in the $1^{\text {st }}$ and $2^{\text {nd }} \mathrm{P} 0$ under $0 \%$ shading and intermittent irrigation.

At the end of the experiment, these characteristics recovered and reached values similar to those of the control group. The values of fluorescence chlorophyll $a$ characteristics observed under conditions of continuous irrigation regardless of shading, are within the reference range, suggesting that the species is sensitive to water deficit.

The greater increase in both F0/Fm and FO in the seedlings under $0 \%$ shading in the P0 periods $\left(1^{\text {st }}\right.$ and $2^{\text {nd }} \mathrm{PO}$ ) associated with reduced $\mathrm{Fv} / \mathrm{Fm}$ and $\mathrm{Fv} / \mathrm{FO}$ suggests the occurrence of photoinhibition under these conditions (Figure 7). Evaluation of these characteristics is important for the success of reforestation projects, as seedlings transplanted to field conditions are exposed to harsh light and other stressors such as drought and heat. Favaretto et al. (2011) reported that photoinhibition causes a slow and reversible reduction of photosynthetic efficiency, indicating that the plant has been subjected to a stressful environment.

The results observed in our research suggest that shading prevents permanent damage to the photosynthetic apparatus in C. xanthocarpa seedlings and minimizes the effects of water deficit, enabling the seedlings to recover under intermittent irrigation. Reinforcing this idea, seedlings under intermittent irrigation and shaded showed higher quality based on IQD.

Similarly, seedlings of Copaifera langsdorffii Desf., which has a wide distribution in the Atlantic and Cerrado forests, presented higher DQI under 50\% and 70\% shading (Reis et al., 2016). One of the best indicators for field and greenhouse survival is DQI because it provides the pattern and morphological parameters of seedlings, such as shoot height, neck diameter, and dry mass (Reis et al., 2016). 


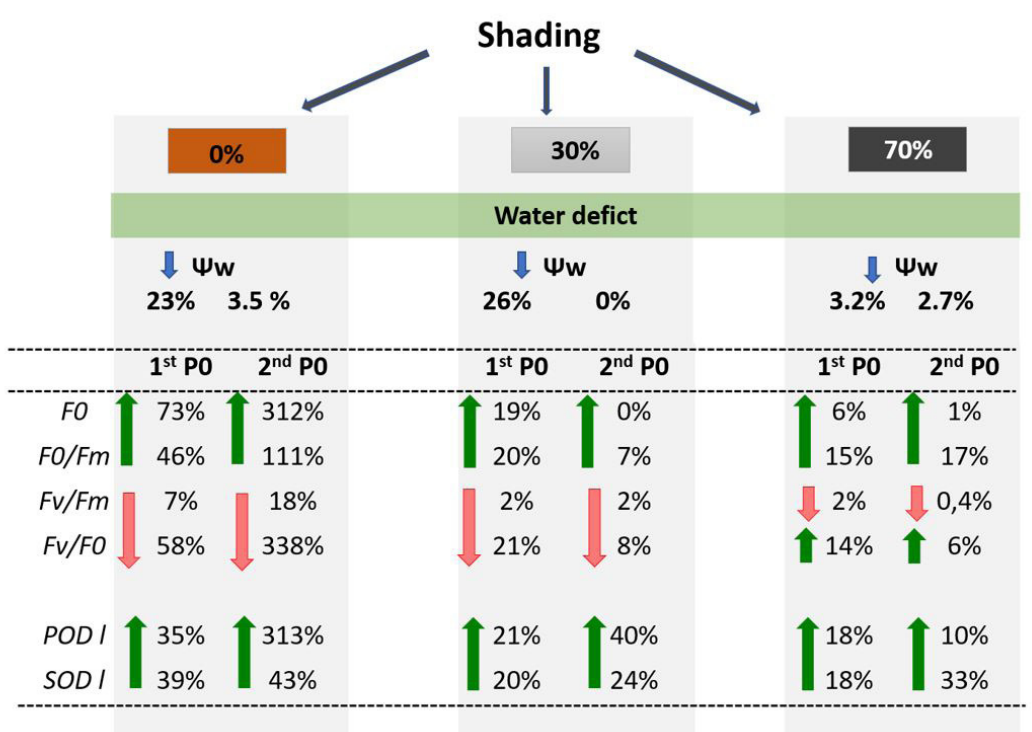

Figure 7. Schematic representation of the effects of shading $(0,30$, and $70 \%)$ on the reduction (\%) of water potential ( $\Psi \mathrm{w})$ in the $1^{\text {st }}$ and $2^{\text {nd }}$ photosynthesis zero (P0) in relation to initial fluorescence (F0), basal quantum production of the non-photochemical processes of photosystem II (F0/Fm), potential quantum efficiency of photosystem II (Fv/Fm), maximum efficiency of the photochemical process in photosystem II (Fv/F0), and peroxidase (POD) and superoxide dismutase (SOD) activities in the leaves of Campomanesia xanthocarpa.

It is interesting to note that the chlorophyll index did not change with water deficit, independent of shading levels. However, the stabilization of values throughout the evaluations up to the $2^{\text {nd }} \mathrm{P} 0$ suggests the detrimental effect of water stress because we could expect an increase in the chlorophyll index with plant growth.

According to the literature, the trend of the chlorophyll index with respect to water deficit is variable, however, decreased in C. xanthocarpa under water deficit and did not recover after hydration (Bento et al., 2016), which contrasts with the results observed for the same species in this study.

In our research, the lants that received 30\% shading maintained lower POD values, however, regardless of shading, the seedlings did not recover, although they showed the lowest enzymatic activity in the roots. Shading maintained lower SOD activity in both organs, even under water deficit. These results confirm the attenuating effect of shading on stress caused by water deficit.

The results demonstrate that when $C$. xanthocarpa seedlings undergo water deficit, enzyme production can combat the reactive oxygen species (ROS) caused by oxidative stress (Egert and Tevini, 2002; Ashraf and Harris, 2013; Gomes Neto et al., 2018). We believe that the effects of oxidative stress were prolonged throughout the evaluations, extending to the final period (106 days) and indicating that the species needs more time to recover from stress. As mentioned in the literature, water deficit can promote oxidative damage and, thus, the plants protect themselves, for example, by synthesizing carotenoids and increasing the activity of enzymes such as POD and SOD in the leaves and roots and reducing the chlorophyll index which favors their adaptative capacity (Gomes Neto et al., 2018).

Similar results have been reported by Bento et al. (2016) for C. xanthocarpa seedlings, in which POD and SOD activities were higher in the leaves in the $1^{\text {st }}$ and $2^{\text {nd }} \mathrm{P} 0$. In studies with generalist species, which are widely distributed and abundant owing to their plasticity, regarding habitat specificity, POD and SOD activities have been evaluated. C. langsdorffii seedlings showed higher SOD activity in the leaves than in the roots, which was observed in the seedlings under intermittent irrigation, the highest values in the leaves were detected under 100\% luminosity (Rosa et al., 2017). For Schinus terebinthifolius Raddi seedlings, the SOD and POD activities were higher in both leaves and roots because of water deficit; the enzymatic activities decreased after rehydration (Nunes et al., 2017).

Thus, the reduction in water potential in C. xanthocarpa seedlings under water restriction and increase in POD and SOD activities under these conditions reinforce the stressful effects of exposure to the sun or mitigating effects of shading on water deficit in this species.

We observed that $C$. xanthocarpa is sensitive to environments with water restriction and our results support the hypothesis that shading minimizes the effects of water deficit. However, we have not been able to prove whether it allows the recovery of antioxidant metabolism in C. xanthocarpa seedlings, since the activity of the enzymes remained high and there was no recovery in the leaves and roots. New studies must be carried out, and the number of recovery days should be increased to see if increasing the time would allow plants to recover POD and SOD activity levels. 
Few studies have evaluated water deficit associated with levels of shading and antioxidant activity in Myrtaceae species. Further studies on Brazilian native species are required because the physiological behaviour of these species under adverse conditions in the field need to be understood to improve the production of quality seedlings and focus on the re-composition of degraded areas.

\section{Conclusion}

C. xanthocarpa is a species sensitive to water deficit but presents strategies to adapt to an environment under temporary water restriction, which are more efficient under shading. The seedlings with water deficit at all levels of shading exhibited higher protective antioxidant activity and lower quality at $0 \%$ shading. The shade levels reduce water stress in the seedlings under intermittent irrigation. The shading minimizes permanent damage to the photosystem II and after the re-irrigation, and the evaluated characteristics showed recovery with respect to the control group, except POD and SOD activities in the leaves.

\section{Acknowledgments}

The authors would like to thank Coordenação de Aperfeiçoamento de Pessoal de Nível Superior (CAPES) and Conselho Nacional de Desenvolvimento Científico e Tecnológico (CNPq - Brazil) for the financial support of this research.

\section{References}

ASHRAF, M. and HARRIS, P.J.C., 2013. Photosynthesis under stress full environments: an overview. Photosynthetica, vol. 51, no. 2, pp. 163-190. http://dx.doi.org/10.1007/s11099-013-0021-6.

BAKER, N.R. and ROSENQVIST, E., 2004. Applications of chlorophyll fluorescence can improve crop production strategies: a examination of future possibilities. Journal of Experimental Botany, vol. 55, no. 403, pp. 1607-1621. http://dx.doi.org/10.1093/ jxb/erh196. PMid:15258166.

BAKER, N.R., 2008. Chlorophyll fluorescence: a probe of photosynthesis in vivo. Annual Review of Plant Biology, vol. 59, no. 1, pp. 89-113. http://dx.doi.org/10.1146/annurev. arplant.59.032607.092759. PMid:18444897.

BARTIERES, E.M.M., SCALON, S.P.Q., DRESCH, D.M., CARDOSO, E.A.S., JESUS, M.V. and PEREIRA, Z.V., 2020. Shading as a means of mitigating water deficit in seedlings of Campomanesia xanthocarpa (Mart.) O. Berg. Notulae Botanicae Horti Agrobotanici Cluj-Napoca, vol. 48, no. 1, pp. 234-244. http://dx.doi. org/10.15835/nbha48111720.

BENTO, L.F., SCALON, S.P.Q., DRESCH, D.M. and PEREIRA, Z.V., 2016. Potential for recovery of Campomanesia xanthocarpa Mart. ex O. Berg seedlings from water deficit. African Journal of Agricultural Research, vol. 11, no. 30, pp. 2775-2785. http:// dx.doi.org/10.5897/AJAR2016.11231.

BROETTO, F., 2014. Métodos de trabalho em bioquímica vegetal e tecnologia de enzimas. São Paulo: UNESP.
CENTRO NACIONAL DE CONSERVAÇÃO DA FLORA - CNCFLORA, 2012 [viewed 13 November 2018]. Campomanesia xanthocarpa. In: Jardim Botânico do Rio de Janeiro - JBRJ. Lista Vermelha da flora brasileira versão 2012 [online]. Rio de Janeiro: CNCFlora. Available from: http://cncflora.jbrj.gov.br/portal/pt-br/profile/ Campomanesia xanthocarpa

CHIRINO, E., RUIZ-YANETTI, S., VILAGROSA, A., MERA, X., ESPINOZA, M. and LOZANO, P., 2017. Morpho-functional traits and plant response to drought conditions in seedlings of six native species of Ecuadorian Ecosystems. Flora, vol. 233, pp. 58-67. http:// dx.doi.org/10.1016/j.flora.2017.05.012.

COSTA, A.C., REZENDE-SILVA, S.L., MEGGUER, C.A., MOURA, L.M.F., ROSA, M. and SILVA, A.A., 2015. The effect of irradiance and water restriction on photosynthesis in young jatobá-do-cerrado (Hymenaea stigonocarpa) plants. Photosynthetica, vol. 53, no. 1, pp. 118-127. http://dx.doi.org/10.1007/s11099-015-0085-6.

DICKSON, A., LEAF, A.L. and HOSNER, J.F., 1960. Quality appraisal of White spruce and white pine seedling stock in nurseries. Forestry Chronicle, vol. 36, no. 1, pp. 10-13. http://dx.doi. org/10.5558/tfc36010-1.

EGERT, M. and TEVINI, M., 2002. Influence of drought on some physiological parameters symptomatic for oxidative stress in leaves of chives (Allium schoenoprasum). Environmental and Experimental Botany, vol. 48, no. 1, pp. 43-49. http://dx.doi. org/10.1016/S0098-8472(02)00008-4.

FAVARETTO, V.F., MARTINEZ, C.A., SORIANI, H.H. and FURRIEL, R.P.M., 2011. Differential responses of antioxidant enzymes in pioneer and late-successional tropical tree species grown under sun and shade conditions. Environmental and Experimental Botany, vol. 70, no. 1, pp. 20-28. http://dx.doi.org/10.1016/j. envexpbot.2010.06.003.

FERREIRA, D.F., 2010 [viewed 13 November 2018]. Programa de análises estatísticas (Statistical Analysis Software) e planejamento de Experimentos - SISVAR 5.3 [online]. Lavras: UFLA. Available from: http://www.scielo.br/pdf/cagro/v35n6/a01v35n6.pdf

FRANCO, A.C., BUSTAMANTE, M., CALDAS, L.S., GOLDSTEIN, G., MEINZER, F.C., KOZOVITS, A.R., RUNDEL, P. and CORADIN, V.T.R., 2005. Leaf functional traits of Neotropical savanna trees in relation to seasonal water deficit. Trees, vol. 19, no. 3, pp. 326-335. http://dx.doi.org/10.1007/s00468-004-0394-z.

GOMES NETO, V., RIBEIRO, P.R., DEL-BEM, L.E., BERNAL, D.T., CUNHA LIMA, S.T., LIGTERINK, W., FERNANDEZ, L.G. and DE CASTRO, R.D., 2018. Characterization of the superoxide dismutase gene family in seeds of two Ricinus communis L. genotypes submitted to germination under water restriction conditions. Environmental and Experimental Botany, vol. 155, pp. 453-463. http://dx.doi.org/10.1016/j.envexpbot.2018.08.001.

KLAFKE, J.Z., SILVA, M.A., PANIGAS, T.F., BELLI, K.C., DE OLIVEIRA, M.F., BARICHELLO, M.M., RIGO, F.K., ROSSATO, M.F., SOARES DOS SANTOS, A.R., PIZZOLATTI, M.G., FERREIRA, J. and VIECILI, P.R.N., 2010. Effects of Campomanesia xanthocarpa on biochemical, hematological and oxidative stress parameters in hypercholesterolemic patients. Journal of Ethnopharmacology, vol. 127, no. 2, pp. 299-305. http://dx.doi.org/10.1016/j. jep.2009.11.004.

LI, Y.G., LI, L.H., JIANG, G.M., NIU, S.L., LIU, M.Z., GAO, L.M., PENG, Y. and JIANG, C.D., 2004. Traits of chlororophyll fluorescence in 99 species from the sparse-elm grassland in Hunshandak Sand land. Photosynthetica, vol. 42, no. 2, pp. 243-249. http:// dx.doi.org/10.1023/B:PHOT.0000040596.39460.6f.

MAXWELL, K. and JOHNSON, G.M., 2000. Chlorophyll fluorescence: a practical guide. Journal of Experimental Botany, vol. 51, no. 345, pp. 659-668. http://dx.doi.org/10.1093/jexbot/51.345.659. PMid:10938857. 
NUNES, D.P., SCALON, S.P.Q., DRESCH, D.M. and GORDIN, C.R.B., 2017. Photosynthetic and enzymatic metabolism of Schinus terebinthifolius Raddi seedlings under water deficit. Ciência e Agrotecnologia, vol. 41, no. 6, pp. 676-682. http://dx.doi. org/10.1590/1413-70542017416005517.

REIS, S.M., MARIMON-JUNIOR, B.H., MORANDI, P.S., SANTOS, C.O., OLIVEIRA, B. and MARIMON, B.S., 2016. Initial development and quality of saplings of Copaifera langsdorffii Desf. under different levels of shading. Ciência Florestal, vol. 26, pp. 11-20. http://dx.doi.org/10.5902/1980509821061.

RESENDE, C.F., PACHECO, V.S., DORNELLAS, F.F., OLIVEIRA, A.M.S., FREITAS, J.C. and PEIXOTO, P.H.P., 2019. Responses of antioxidant enzymes, photosynthetic pigments and carbohydrates in micropropagated Pitcairnia encholirioides L.B. Sm. (Bromeliaceae) under ex vitro water deficit and after rehydration. Brazilian Journal of Biology $=$ Revista Brasileira de Biologia, vol. 79, no. 1, pp. 52-62. http://dx.doi.org/10.1590/1519-6984.175284. PMid:29590251.

RODRIGUES, P.M.S.A., SILVA, J.O.B., EISENLOHR, P.V. and SCHAEFER, C.E., 2015. Climate change effects on the geographic distribution of specialist tree species of the Brazilian tropical dry forests.
Brazilian Journal of Biology = Revista Brasileira de Biologia, vol. 75, no. 3, pp. 679-684. http://dx.doi.org/10.1590/1519-6984.20913. PMid:26465729.

ROHÁCEK, K., 2002. Chlorophyll fluorescence parameters: the definitions, photosynthetic meaning, and mutual relationships. Photosynthetica, vol. 40, no. 1, pp. 13-29. http://dx.doi. org/10.1023/A:1020125719386.

ROSA, D.B., SCALON, S.P.Q., CREMON, T., CECCON, F. and DRESCH, D.M., 2017. Gas exchange and antioxidant activity in seedlings of Copaifera langsdorffii Desf. under diferent water conditions. Anais da Academia Brasileira de Ciências, vol. 89, no. 4, pp. 30393050. http://dx.doi.org/10.1590/0001-3765201720170499. PMid:29267801.

TAIZ, L., ZEIGER, E., MOLLER, I.M. and MURPHY, A., 2017. Plant physiology and development. 6. ed. Porto Alegre: Artmed, 858 p.

TELEGINSKI, F., ZUFFELLATO-RIBAS, K.C., KOEHLER, H.S., DEGENHARDT-GOLDBACH, J. and TELEGINSKI, E., 2018. Vegetative propagation of Campomanesia xanthocarpa Mart. ex O.Berg by air layering. Ciência Florestal, vol. 28, no. 2, pp. 820-826. http://dx.doi.org/10.5902/1980509832100. 